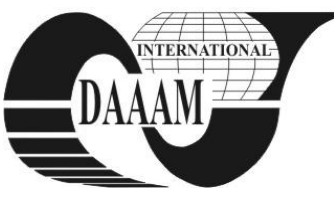

\title{
ASSESSMENT OF ENERGY PRODUCTION AND ENERGY BALANCE FOR THE ADAPTATION OF WIND MICRO-AGGREGATES AT A COMPARATIVE ANALYSIS
}

\author{
DUBAU, C[alin] \& CATAS, A[driana]
}

\begin{abstract}
The work intends to make a synthetic presentation of an assessment method of the production of energy and energy balance in the conditions of adaptation of wind microaggregates at a comparative analysis, by determining certain energy parameters which are used in design calculations, obtaining the total production of energy $\mathrm{kwh} / \mathrm{year}$.

Key words: energy assessment, turbine, electric generator, energy balance, system
\end{abstract}

\section{INTRODUCTION}

In the process of assessment of a turbine, the installation point represents a pair of values $\left(P_{a i}, v_{i}\right)$ for which the system is dimensioned, where $P_{a i}$ represents the largest power at which the system may work.

The turbine's energy balance refers to determining certain energy parameters, which are used in the design calculation, for the adaptation of wind aggregates to the requirements of a comparative analysis (Dubău, 2007; Bej, 2003).

\section{MATERIAL AND METHOD}

For assessments during the design were used three positions of powers (Gyulai, 2000, 2003), that is:

- valorized power by the turbine's blading $\left(P_{p a l}\right)$;

- power at spindle (coupling between turbine and generator) $\left(P_{a r b}\right)$;

- electric power at the generator's marker stones $\left(P_{e b}\right)$

For the dynamic behaviour of the group of machines were identified the curves for the engine moment of the turbine and for the resistant moment of the electric generator.

For these analyzed were used experimental programs.

In the area of maximum powers the three levels of powers had the following orientative values:

$$
P_{e b} \cong 2500 \mathrm{~W}, P_{a r b} \cong 2800 \mathrm{~W}, P_{p a l} \cong 3000 \mathrm{~W} \text {. }
$$

The power at markers stones at the nominal point has the value of $2000 \mathrm{~W}$, and the nominal speed is of $250 \mathrm{rpm}$, and in an accepted functioning field we have for $\mathrm{n}=40 \ldots 500 \mathrm{rpm}$.

The power installed at the electric generator's marker stones was established at $2500 \mathrm{~W}$ and this was based on the results of an economic efficiency study.

By correlating the performances of the three dimensions of turbines with the electric generator, where the level of limited power ws considered at the level of $3 \mathrm{~kW}$ (at the turbine's spindle), different limitation speeds are accepted. The management system shall select the speed in relation to the admitted electric power in the generator's winding.

The parameters which define the turbine's gauge are the diameter $(D)$ and the height of the blading $(H)$. In these conditions, the exposed area is calculated with the formula $A=$ $D \cdot H$ and the relation of power at the spindle is

$$
P_{a}=C_{P a} \cdot \rho \cdot \frac{v^{3}}{2} \cdot D \cdot H,
$$

where $\rho$ is the air's density which depends on the altitude of the sea level and the air's temperature; $\mathrm{v}$ - air speed depends on time and elevation of the place; $C_{P a}$ depends on the characteristic number

$$
\lambda=\frac{\text { peripheral } . \text { speed }}{\text { wind } \text {.speed }}
$$

\section{RESULTS AND DISSCUSIONS}

The assessment of energy production and the energy balance for the three dimensions of the turbine have the following determined values such as:

3.1 The assessment of energy production and the energy balance in the case of Turbine $T 32$

We have the parameters: Turbine $T 32\left(\lambda_{o}=3\right), S=4,5 \mathrm{~m}^{2}$ $D=1,5 \mathrm{~m}$; Location's offer: $v_{m}=6 \mathrm{~m} / \mathrm{s}$, Const. $k=0,73$; Air

\begin{tabular}{|c|c|c|c|c|c|c|c|}
\hline$\underset{[\mathrm{m} / \mathrm{s}]}{\mathrm{V}}$ & $\begin{array}{c}\mathrm{F} \\
\text { [hours/ } \\
\text { year] }\end{array}$ & $\mathrm{C}_{\mathrm{P}}$ & $\mathrm{P}_{\mathrm{T}}[\mathrm{W}]$ & $\begin{array}{c}\mathrm{n} \\
{[\mathrm{rpm}]}\end{array}$ & $\begin{array}{c}\eta_{\mathrm{G}} \\
{[\%]}\end{array}$ & $\mathrm{P}_{\mathrm{G}}[\mathrm{W}]$ & $\begin{array}{c}\text { Prod. of } \\
\text { energy at } \\
\text { marker } \\
\text { stones } \\
{[\mathrm{kWh} / \mathrm{an}]}\end{array}$ \\
\hline 2 & 934 & 0,45 & 10 & 76 & 6 & 0,6 & 0,6 \\
\hline 3 & $\begin{array}{c}103 \\
1\end{array}$ & 0,45 & 35 & 115 & 8 & 2,8 & 2,9 \\
\hline 4 & $\begin{array}{c}103 \\
5\end{array}$ & 0,45 & 79 & 153 & 20 & 15,8 & 16,4 \\
\hline 5 & 969 & 0,45 & 156 & 191 & 32 & 49,9 & 48,4 \\
\hline 6 & 858 & 0,45 & 267 & 229 & 56 & 149,5 & 128,3 \\
\hline 7 & 723 & 0,45 & 425 & 267 & 76 & 323,0 & 233,5 \\
\hline 8 & 583 & 0,45 & 636 & 306 & 81 & 515,2 & 300,4 \\
\hline 9 & 452 & 0,45 & 905 & 344 & 86 & 778,3 & 351,8 \\
\hline 10 & 338 & 0,45 & 1242 & 382 & 88 & 1093,0 & 369,4 \\
\hline 11 & 244 & 0,45 & 1651 & 420 & 89 & 1469,4 & 358,5 \\
\hline 12 & 170 & 0,45 & 2143 & 458 & 90 & 1928,7 & 327,9 \\
\hline 13 & 115 & 0,45 & 2726 & 497 & 90 & 2453,4 & 282,1 \\
\hline 14 & 75 & 0,397 & 3000 & 472 & 90 & 2700,0 & 202,5 \\
\hline 15 & 48 & 0,322 & 3000 & 411 & 90 & 2700,0 & 129,6 \\
\hline 16 & 29 & 0,266 & 3000 & 391 & 90 & 2700,0 & 78,3 \\
\hline 17 & 18 & 0,222 & 3000 & 379 & 90 & 2700,0 & 48,6 \\
\hline 18 & 10 & 0,187 & 3000 & 367 & 90 & 2700,0 & 27,0 \\
\hline 19 & 6 & 0,159 & 3000 & 363 & 90 & 2700,0 & 16,2 \\
\hline 20 & 3 & 0,136 & 3000 & 357 & 90 & 2700,0 & 8,1 \\
\hline \multicolumn{7}{|c|}{ Total energy $[\mathrm{kWh} /$ year $]$ : } & 2930,5 \\
\hline
\end{tabular}
density: $\rho=1,225 \mathrm{~kg} / \mathrm{m}^{3}$.

The assessment of energy production is shown in Table 1.

Tab. 1. The assessment of energy production and the energy balance in the case of Turbine $\mathrm{T} 32$ 


\subsection{The assessment of energy production and energy} balance in the case of Turbine $T 33$

We have the parameters: Turbine $T 33\left(\lambda_{o}=3\right), S=6 \mathrm{~m}^{2}$ $D=2 \mathrm{~m}$; Location's offer: $v_{m}=5 \mathrm{~m} / \mathrm{s}$, Const. $k=0,73$; Air density: $\rho=1,225 \mathrm{~kg} / \mathrm{m}^{3}$.

The assessment of energy production is shown in Table 2 .

\begin{tabular}{|c|c|c|c|c|c|c|c|}
\hline $\begin{array}{l}\mathrm{V} \\
{[\mathrm{m} /} \\
\mathrm{s}]\end{array}$ & $\begin{array}{c}\mathrm{F} \\
\text { [hours/ } \\
\text { year] }\end{array}$ & $C_{P}$ & $\begin{array}{c}\mathrm{P}_{\mathrm{T}} \\
{[\mathrm{W}]}\end{array}$ & $\begin{array}{l}\mathrm{n} \\
{[\mathrm{rp}} \\
\mathrm{m}]\end{array}$ & $\begin{array}{c}\eta_{\mathrm{G}} \\
{[\%]}\end{array}$ & $\begin{array}{c}\mathrm{P}_{\mathrm{G}} \\
{[\mathrm{W}]}\end{array}$ & $\begin{array}{c}\text { Prod. of } \\
\text { energy at } \\
\text { marker stones } \\
{[\mathrm{kWh} / \mathrm{an}]}\end{array}$ \\
\hline 2 & 1186 & 0,45 & 13 & 57 & 7 & 0,9 & 1,1 \\
\hline 3 & 1194 & 0,45 & 46 & 86 & 35 & 16,1 & 19,2 \\
\hline 4 & 1097 & 0,45 & 105 & 115 & 63 & 66,2 & 72,6 \\
\hline 5 & 943 & 0,45 & 208 & 143 & 78 & 162,2 & 152,9 \\
\hline 6 & 768 & 0,45 & 356 & 172 & 79 & 281,2 & 215,9 \\
\hline 7 & 598 & 0,45 & 567 & 201 & 84 & 476,3 & 284,8 \\
\hline 8 & 446 & 0,45 & 848 & 229 & 85 & 720,8 & 321,5 \\
\hline 9 & 321 & 0,45 & 1207 & 258 & 86 & 1038,0 & 333,2 \\
\hline 10 & 223 & 0,45 & 1655 & 286 & 88 & 1456,4 & 324,8 \\
\hline 11 & 150 & 0,45 & 2200 & 315 & 90 & 1980,0 & 297,0 \\
\hline 12 & 98 & 0,45 & 2857 & 344 & 90 & 2571,3 & 252,0 \\
\hline 13 & 62 & 0,37 & 3000 & 292 & 88 & 2640,0 & 163,7 \\
\hline 14 & 39 & 0,29 & 3000 & 274 & 88 & 2640,0 & 103,0 \\
\hline 15 & 23 & 0,24 & 3000 & 261 & 87 & 2610,0 & 60,0 \\
\hline 16 & 14 & 0,19 & 3000 & 252 & 88 & 2640,0 & 37,0 \\
\hline 17 & 8 & 0,16 & 3000 & 244 & 87 & 2610,0 & 20,9 \\
\hline 18 & 4 & 0,14 & 3000 & 241 & 86 & 2580,0 & 10,3 \\
\hline 19 & 1 & 0,11 & 3000 & 233 & 86 & 2580,0 & 2,6 \\
\hline 20 & 0 & 0 & 0 & - & - & - & - \\
\hline \multicolumn{7}{|c|}{ Total energy $[\mathrm{kWh} / \mathrm{year}]$} & 2672,5 \\
\hline
\end{tabular}

Tab. 2. The assessment of energy production and energy balance in the case of Turbine T 33

\subsection{The assessment of energy production and energy} balance in the case of Turbine $\mathrm{T} 34$

We have the parameters: Turbine $T 34\left(\lambda_{o}=3\right), S=7,5 \mathrm{~m}^{2}$ $D=2,5 \mathrm{~m}$; Location's offer: $v_{m}=4 \mathrm{~m} / \mathrm{s}$, Const. $k=0,73$; Air density: $\rho=1,225 \mathrm{~kg} / \mathrm{m}^{3}$.

The assessment of energy production is shown in Table 3.

\begin{tabular}{|c|c|c|c|c|c|c|c|}
\hline $\begin{array}{c}\mathrm{V} \\
{[\mathrm{m} / \mathrm{s}]}\end{array}$ & $\begin{array}{c}\mathrm{F} \\
{[\text { hours/ }} \\
\text { year] }\end{array}$ & $\mathrm{C}_{\mathrm{P}}$ & $\begin{array}{c}\mathrm{P}_{\mathrm{T}} \\
{[\mathrm{W}]}\end{array}$ & $\begin{array}{c}\mathrm{n} \\
{[\mathrm{rpm}]}\end{array}$ & $\begin{array}{c}\eta_{\mathrm{G}} \\
{[\%]}\end{array}$ & $\mathrm{P}_{\mathrm{G}}[\mathrm{W}]$ & $\begin{array}{c}\text { Prod. of } \\
\text { energy } \\
\text { at } \\
\text { marker } \\
\text { stones } \\
{[\mathrm{kWh} / \mathrm{a}} \\
\mathrm{n}]\end{array}$ \\
\hline 2 & 1450 & 0,45 & 17 & 46 & 6 & 1,0 & 1,5 \\
\hline 3 & 1289 & 0,45 & 57 & 69 & 40 & 22,8 & 29,4 \\
\hline 4 & 1057 & 0,45 & 132 & 92 & 70 & 92,4 & 97,7 \\
\hline 5 & 818 & 0,45 & 260 & 115 & 80 & 208,0 & 170,1 \\
\hline 6 & 604 & 0,45 & 445 & 138 & 82 & 364,9 & 220,4 \\
\hline 7 & 428 & 0,45 & 709 & 160 & 86 & 609,7 & 261,0 \\
\hline 8 & 294 & 0,45 & 1060 & 183 & 86 & 911,6 & 268,0 \\
\hline 9 & 195 & 0,45 & 1509 & 206 & 87 & 1312,8 & 256,0 \\
\hline 10 & 126 & 0,45 & 2069 & 229 & 87 & 1800,0 & 226,8 \\
\hline
\end{tabular}

\begin{tabular}{|c|c|c|c|c|c|c|c|}
\hline 11 & 80 & 0,45 & 2751 & 252 & 87 & 2393,4 & 191,5 \\
\hline 12 & 49 & 0,378 & 3000 & 215 & 85 & 2550,0 & 125,0 \\
\hline 13 & 29 & 0,297 & 3000 & 204 & 83 & 2490,0 & 72,2 \\
\hline 14 & 17 & 0,238 & 3000 & 193 & 83 & 2490,0 & 42,3 \\
\hline 15 & 9 & 0,193 & 3000 & 183 & 82 & 2460,0 & 22,1 \\
\hline 16 & 5 & 0,159 & 3000 & 177 & 81 & 2430,0 & 12,2 \\
\hline 17 & 2 & 0,133 & 3000 & 182 & 82 & 2460,0 & 4,9 \\
\hline 18 & 0 & 0 & 0 & - & - & - & - \\
\hline \multicolumn{7}{|c|}{ Total energy [kWh/year] : } \\
\hline
\end{tabular}

Tab. 3. The assessment of energy production and energy balance in the case of Turbine T 34

These tables emphasize assessments of production of energy and energy banalce for the three types of turbine, offering in this manner the possibility of adaptation of turbines to the specific requirements.

In the Figure 1 we can notice the correlation between the performances of the turbine with the generator performance.

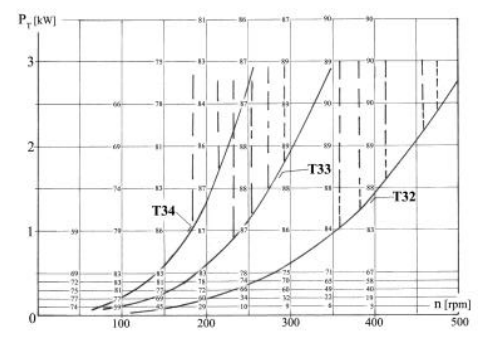

Fig.1. Performance of the turbine

\section{CONCLUSIONS}

By analyzing these results presented in relation to the energy reports regarding the adaptation of turbines to the specific requirements, the conclusions are as follows:

- it is necessary a better corellation of performances of the two machines (turbine and generator) with the objective of maximizing the product $\left(C_{p} * \eta_{G}\right)$.

- the size of turbine's area exposed, with the condition of complying to the restrictions imposed.

- optimal management of the aggregate through controlling the speed (variable for $C_{P \max }$ and constant for limitation of power).

- verification of energy calculation for the favourable variability of the location's offer (const. $k=0,73$ ).

\section{REFERENCES}

Bej, A. (2003). Wind turbines, "Power" collection, Politehnica Publishing House, ISBN 973-625-098-9, pp. 43-44, Timişoara, Romania

Dubău, C. (2007). Using wind microagregate in complex systems, Politehnica Publishing House, ISSN: 1842-4937, ISBN: 978-973-625-408-6, pp. 150-157, Timişoara, Romania

Gyulai, Fr. (2000). Specialization course in sustainable energy technologies. Modules: Installations Wind and Wind Units, Timişoara

Gyulai, Fr. (2003). Contributions on horizontal axis wind turbine theory, The $5^{\text {th }}$ International Conference on Hydraulic Machinery and Hydrodynamics, Timişoara, România

Gyulai, Fr. (2003). Vocational Traning in Sustainable EnergyCourse Wind Energy 